\title{
PENGEMBANGAN KONTEN DALAM MENINGKATKAN EFEKTIVITAS PEMBELAJARAN DARING DI MADRASAH ALIYAH NEGERI 4 KOTA PEKANBARU
}

\author{
Syahtriatna Djusar*1), Fajrizal2), Elvira Asril ${ }^{3)}$ \\ 1,2,3 Fakultas Ilmu Komputer, Universitas Lancang Kuning \\ e-mail: eet@unilak.ac.id ${ }^{1}$, fajrizal@unilak.ac.id ${ }^{2}$, elvira@unilak.ac.id ${ }^{3}$
}

\begin{abstract}
Abstrak : Aplikasi adalah suatu perangkat lunak yang dibuat khusus untuk memenuhi kebutuhan berbagai aktivitas dan pekerjaan. Layanan Aplikasi berkembang seiring dengan perkembangan kebutuhan user dan perkembangan perangkat Teknologi Informasi. Salah satu kemampuan yang diberikan oleh Aplikasi adalah dalam layanan di bidang pendidikan. Berbagai layanan yang terkait dengan dunia pendidikan dapat dipermudah dengan keberadaan sebuah aplikasi. Penggunaan aplikasi untuk pendidikan akan membantu proses pembelajaran di MAN 4 Kota Pekanbaru. Dengan memanfaatkan aplikasi untuk membuat konten pembelajaran, pembelajaran yang dilakukan secara daring akan menjadi mudah dan menarik, sehingga apabila ada kendala atau hambatan pada proses pembelajaran tatap muka seperti dalam kondisi wabah Covid-19 pada saat ini, maka proses pembelajaran tetap dapat dilakukan, dimana guru dan siswa tidak harus berada di satu ruang belajar tertentu. Pelaksanaan kegiatan workshop dan pelatihan kepada 21 orang guru MAN 4 Kota Pekanbaru menggunakan aplikasi Powerpoint, Camtasia, Video Scribe dan Youtube, telah meningkatkan pengetahuan dan keterampilan guru dalam memanfaatkan aplikasi untuk mengembangkan konten bagi pembelajaran daring, khususnya pada aplikasi camtasia yang pada awalnya hanya 3 orang guru yang pernah mengenal aplikasi tersebut, pada akhir kegiatan, semua peserta dapat mengenal aplikasi camtasia.
\end{abstract}

Kata kunci: Pembelajaran Daring, Efektivitas Pembelajaran, Covid-19, Pengembangan Konten

\begin{abstract}
Application is a software that is made specifically to meet the needs of various activities and jobs. Application Services develop along with the development of user needs and the development of Information Technology devices. One of the capabilities provided by the Application is in services in the field of education. Various services related to the world of education can be facilitated by the existence of an application. The use of applications for education will help the learning process at MAN 4 Pekanbaru City. By utilizing applications to create learning content, online learning will be easy and interesting, so that if there are obstacles or obstacles in the face-to-face learning process such as in the current Covid-19 outbreak conditions, the learning process can still be carried out, where the teacher and students do not have to be in one particular study room. The implementation of workshops and training for 21 teachers of MAN 4 Pekanbaru City using the Powerpoint application, Camtasia, Video Scribe and Youtube, has increased the knowledge and skills of teachers in using applications to develop content for online learning, especially on the Camtasia application which was initially only 3 people. teachers who have been familiar with the application, at the end of the activity, all participants can get to know the Camtasia application.
\end{abstract}

Keywords: Online Learning, Learning Effectiveness, Covid-19, Content Development

\section{Pendahuluan}

Pandemi virus Covid-19 di Indonesia sudah memasuki bulan ketujuh dan belum ada tandatanda kapan akan berakhir. Saat penderita positif pertama kali disampaikan pada bulan Maret tahun 2020, hingga Senin (19/10/2020), sebanyak 361,867 orang dinyatakan positif terinfeksi Covid-19 dengan jumlah sebanyak 285,324 orang di antaranya dinyatakan sembuh. Meski begitu, sebanyak 12,511 orang lainnya dinyatakan meninggal dunia. Covid-19 merupakan suatu wabah dari yang berasa dari virus dan bersifat menular, yang akan dapat menyebar antara satu orang dengan orang lainnya, dengan bentuk penyebaran yang beragam, dan hingga hari ini penelitian 
tentang cara penyebaran virus ini terus dilakukan. Virus ini akan menyerang rangkaian sistem pernapasan, diantaranta hidung, tenggorokan, dan paru-paru. Sulitnya penanganan wabah yang disebabkan berbagai hal, belum ditemukannya suatu vaksin dan obat untuk penyembuhan pasien Covid-19 yang sudah terbukti dan teruji serta terbatasnya alat pelindung diri (APD) untuk tenaga kesehatan, telah membuat pemerintah menerapkan bberbagai kebijakan ketat untuk memutus rantai penyebaran Covid-19.

Salah satu kebijakan yang diterapkan oleh pemerintah adalah menutup proses belajar mengajar secara tatap muka di seluruh satuan pendidikan, khususnya daerah yang di kategorikan pandemic atau dikenal dengan daerah merah. Pelaksanaan pembelajaran di seluruh satuan pendidikan dialihkan menjadi pembelajaran daring atau blended (semi daring). Semua komponen pendidikan di dorong untuk memanfaatkan sarana dan teknologi informasi untuk dapat melakukan pendidikan secara daring ini. Untuk menunjang kegiatan ini pemerintah telah melaksanakan banyak hal dan bekerja sama dengan berbagai pihak. Salah satunya adalah pemberian pulsa untuk peserta belajar dan tenaga pendidik. Hal yang sama juga didapatkan oleh jenjang pendidikan sekolah menengah atas. Guru dan siswa menerima bantuan pulsa dari pemerintah untuk menunjang pembelajaran daring.

Undang-undang pendidikan pasal 1 ayat 20(Diknas, 2003) yang menyebutkan bahwa pembelajaran adalah proses interaksi peserta didik dengan pendidik dan sumber belajar pada suatu lingkungan belajar. Menurut pada ahli, diantaranya(Holford, 2003)(Joyce \& Weil, 2003)(Hall \& Greeno, 2012) pembelajaran adalah sistem interaksi antara pendidik dan peserta didik, dengan tujuan membantu siswa dalam proses belajar, yang merupakan urutan peristiwa yang telah di rancang dan di susun sedemikian rupa yang berguna dalam mempengaruhi dan mendukung terjadinya proses belajar siswa yang bersifat internal. Penggunaan aplikasi akam memberikan berbagai kemudahan dalam proses pendidikan(Costaner, Febriadi, \& others, 2020).

Sistem pembelajaran daring (dalam jaringan) merupakan sistem pembelajaran tanpa tatap muka secara langsung antara guru dan siswa tetapi dilakukan melalui online yang menggunakan jaringan internet. Guru harus memastikan kegiatan belajar mengajar tetap berjalan, meskipun siswa berada di rumah(Siddiq, Gochyyev, \& Wilson, 2017)(Ghislandi, 2012)(Dhawan, 2020)(Dhika, Destiawati, Surajiyo, \& Jaya, 2021)(Taslim, Toresa, \& Djusar, 2017)(Trivantis, 2016).

Menurut (George, 2020)(Rodrigues, 2018)efektivitas pembelajaran diartikan berhasil guna atau tepat guna, atau mencapai tujuan atau pencapaian tujuan pembelajaran. Dalam hal ini efektifitas pembelajaran atau pembelajaran yang efektif adalah usaha yang membuahkan hasil atau menghasilkan belajar yang bermanfaat dan bertujuan bagi para peserta belajar, melalui pemakaian prosedur yang tepat. Dalam definisi ini kata efektifitas pembelajaran mengandung dua indicator penting, yaitu terjadinya belajar pada peserta belajar dan apa yang dilakukan tenaga pengajar. Dengan demikian, prosedur pembelajaran yang dipakai oleh tenaga pengajar dan bukti peserta belajar akan dijadikan fokus dalam usaha pembinaan efektifitas pembelajaran. Dalam aspek teori yang lain efektivitas diartikan "kemampuan untuk melakukan hal yang tepat atau menyelesaikan sesuatu dengan baik". Vygotsky(Derry, n.d.)berpendapat bahwa pengalaman interaksi sosial (efektifitas) merupakan hal penting bagi perkembangan keterampilan berfikir (thinking skill). Instructional Effectiveness tergantung pada lima faktor: 1) Attitude; 2) Ability to Understand Instruction; 3)Perseverance; 4) Opportunity; 5) Quality of Instruction .

Dalam proses pembelajaran, efektifitas yang diukur adalah aplikasi yang digunakan, konten yang ada pada pembelajaran, perangkat yang digunakan, waktu yang dipakai, biaya yang digunakan, interaksi antara guru dan siswa.

Pembelajaran daring ini menimbulkan kesulitan bagi berbagai pihak, diantaranya guru dan murid. Sebagian guru tidak memiliki kememapuan dan keterampilan dalam menggunakan aplikasi untuk mempersiapkan konten pembelajaran daring. Akibatnya konten yang dihasilkan menjadi tidak efektif karena menyulitkan siswa dalam mengakses dan mamahaminya. Selain itu, konten yang disajikan juga tidak dapat menumbuhkan ketertarikan siswa, karena terkesan monoton, tidak variatif dan tidak interaktif. 


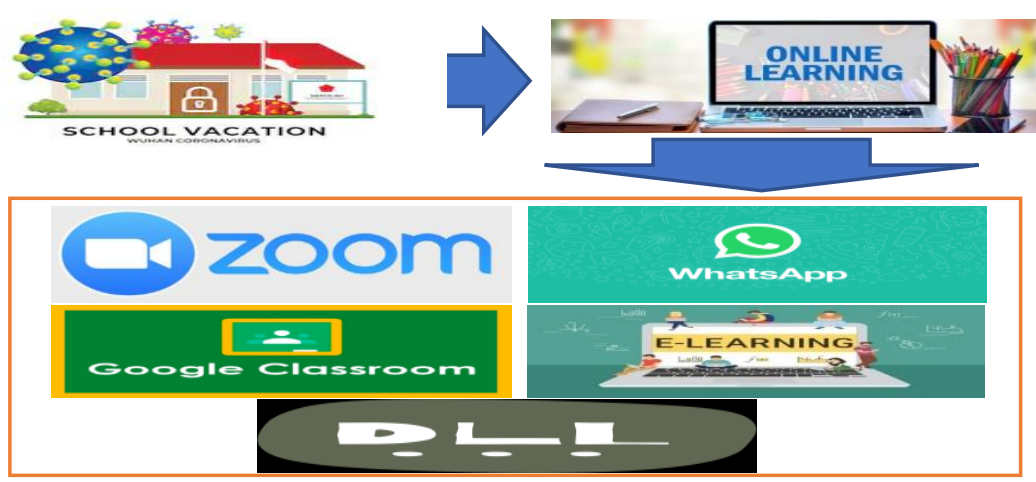

Gambar 1. Analisa Situasi

\section{Metode}

Metode pelaksanaan pengabdian ini adalah dengan mengadakan pelatihan atau workshop tentang bagaimana cara menggunakan aplikasi Camtasia, Video Scribe, Youtube dalam membantu proses pembelajaran daring yang dilakukan secara daring, karena mengingat himbauan pemerintah tentang kepatuhan terhadap protocol kesehatan pada masa pandemic Covid-19. Kegiatan ini dibagi dalam beberapa tahapan, yaitu:

- Tahap pertama yaitu fase penyuluhan, setiap peserta akan diberikan pengarahan terlebih dahulu mengenai pengetahuan tentang aplikasi Camtasia, Video Scribe, Youtube.

- Tahap kedua, dilakukan Evaluasi awal, dilakukan sebelum workshop dilaksanakan. Aktvitas evaluasi ini dilakukan melalui kuisioner daring untuk mengetahui kemampuan dan keterampilan awal guru sebagai peserta dalam menggunakan aplikasi Camtasia, Video Scribe, Youtube

- Tahap ketiga yaitu fase demonstrasi dan pelatihan (praktek). Setiap peserta akan diberikan modul /panduan penggunaan Aplikasi dengan materi Camtasia, Video Scribe, Youtube, kemudian peserta akan dibimbing menggunakan aplikasi yang ada.

- Tahap kempat yaitu Evaluasi proses, dilakukan pada saat kegiatan sedang berlangsung. Aktivitas yang dievaluasi adalah mengamati minat peserta untuk melakukan tanya jawab dan diskusi mengenai tema pelatihan yang disajikan.

- Tahap kelima yaitu fase evaluasi hasil, dilakukan setelah workshop dilaksanakan. Aktvitas evaluasi ini dilakukan melalui kuisioner daring untuk mengetahui kemampuan dan keterampilan akhir guru sebagai peserta dalam menggunakan aplikasi Camtasia, Video Scribe, Youtube.

Mitra akan menyediakan atau mengusulkan guru-guru yang akan mengikuti kegiatan workshop. Selain itu, mitra juga menyediakan sendiri perangkat komputer, aplikasi dan koneksi internetnya.

Agar program ini dapat diimplementasikan dan berlanjut, maka tim pengabdian akan memberikan sertifikat workshop durasi 32 jam pelajaran dengan persayaratan tertentu, diantaranya peserta pelatihan harus mengikuti kegiatan secara aktif dari awal hingga akhir, peserta harus membuat produk konten pembelajaran dan peserta harus memperlihatkan/ mengirimkan konten tersebut kepada tim pengabdian. Dengan demikian, maka kegiatan ini benar-benar dapat direalisasikan dan berjalan secara berkelanjutan selama proses pembelajaran daring. 


\section{Hasil dan Pembahasan}

Tabel 1.Data Peserta

\begin{tabular}{|c|c|c|c|c|}
\hline NO & NAMA PESERTA & $\begin{array}{l}\text { ASAL SEKOLAH/ } \\
\text { INSTITUS }\end{array}$ & $\begin{array}{l}\text { Nomor HP } \\
\text { / WA }\end{array}$ & EMAIL \\
\hline 1 & EGA ANGGRAINI, S.PD.I & $\begin{array}{l}\text { MAN } 4 \text { KOTA } \\
\text { PEKANBARU }\end{array}$ & $\begin{array}{l}8238871871 \\
5\end{array}$ & anggrainiega@gmail.com \\
\hline 2 & MARSAL HALIS, S.PD & MTSN 1 PEKANBARU & $\begin{array}{l}8536490803 \\
4\end{array}$ & marsalhalis@gmail.com \\
\hline 3 & MUHAMMAD FUAD & $\begin{array}{l}\text { MAN } 4 \text { KOTA } \\
\text { PEKANBARU }\end{array}$ & 8126811635 & $\begin{array}{l}\text { muhammadfuad1971@gmail.co } \\
\text { m }\end{array}$ \\
\hline 4 & ENDAH SEFTIANI, S. PD & $\begin{array}{l}\text { MAN } 4 \text { KOTA } \\
\text { PEKANBARU }\end{array}$ & $\begin{array}{l}8965510186 \\
1\end{array}$ & endah.seftiani123@gmail.com \\
\hline 5 & MAISYARAH,S.PD & $\begin{array}{l}\text { MAN } 4 \text { KOTA } \\
\text { PEKANBARU }\end{array}$ & $\begin{array}{l}8137810051 \\
2\end{array}$ & maisyarah4@gmail.com \\
\hline 6 & LIA AMALIA AZZAHRA & $\begin{array}{l}\text { MAN } 4 \text { KOTA } \\
\text { PEKANBARU }\end{array}$ & $\begin{array}{l}8137810051 \\
2\end{array}$ & amalia2766@gmail.com \\
\hline 7 & $\begin{array}{l}\text { IRADATUL HASANAH, } \\
\text { S.PD }\end{array}$ & $\begin{array}{l}\text { MAN } 4 \text { KOTA } \\
\text { PEKANBARU }\end{array}$ & $\begin{array}{l}8238463963 \\
1\end{array}$ & iradatulhasanah93@gmail.com \\
\hline 8 & $\begin{array}{l}\text { OLOAN HARAHAP, } \\
\text { S.PD.I, MA }\end{array}$ & $\begin{array}{l}\text { MAN } 4 \text { KOTA } \\
\text { PEKANBARU }\end{array}$ & 8127650311 & $\begin{array}{l}\text { Oloanharahapoloan@yahoo.co } \\
\text { m }\end{array}$ \\
\hline 9 & $\begin{array}{l}\text { NURMAN SETIAWAN, S. } \\
\text { SOS }\end{array}$ & $\begin{array}{l}\text { MAN } 4 \text { KOTA } \\
\text { PEKANBARU }\end{array}$ & $\begin{array}{l}8536354667 \\
7 \\
\end{array}$ & Nurmansetiawan23@gmail.cok \\
\hline 10 & $\begin{array}{l}\text { ANAH MUTASLIMAH, } \\
\text { S.PD }\end{array}$ & $\begin{array}{l}\text { MAN } 4 \text { KOTA } \\
\text { PEKANBARU }\end{array}$ & $\begin{array}{l}8127593375 \\
6\end{array}$ & Amutaslimah@gmail.com \\
\hline 11 & $\begin{array}{l}\text { AGUS SALIM TANJUNG, } \\
\text { MA }\end{array}$ & $\begin{array}{l}\text { MAN } 4 \text { KOTA } \\
\text { PEKANBARU }\end{array}$ & $\begin{array}{l}8137864955 \\
6\end{array}$ & agustanjung8058@gmail.com \\
\hline 12 & $\begin{array}{l}\text { VINA NURI AMELIA, } \\
\text { S.PD.I }\end{array}$ & $\begin{array}{l}\text { MAN } 4 \text { KOTA } \\
\text { PEKANBARU }\end{array}$ & $\begin{array}{l}8536308199 \\
7\end{array}$ & vina.nuri.amelia.74@gmail.com \\
\hline 13 & DESTARIOSADI, S.SOS & $\begin{array}{l}\text { MAN } 4 \text { KOTA } \\
\text { PEKANBARU }\end{array}$ & $\begin{array}{l}8126674060 \\
7\end{array}$ & deatary089@gmail.com \\
\hline 14 & $\begin{array}{l}\text { ADILLAH HARNIATI, } \\
\text { S.PD }\end{array}$ & $\begin{array}{l}\text { MAN } 4 \text { KOTA } \\
\text { PEKANBARU }\end{array}$ & $\begin{array}{l}8127557592 \\
1\end{array}$ & adillahharniati08@gmail.com \\
\hline 15 & CHOLID & $\begin{array}{l}\text { MAN } 4 \text { KOTA } \\
\text { PEKANBARU }\end{array}$ & $\begin{array}{l}8216364455 \\
7 \\
\end{array}$ & cholidmthayib@gmail.com \\
\hline 16 & $\begin{array}{l}\text { MARIANA HERISTIAN, } \\
\text { S.PD }\end{array}$ & SMP NEGERI 9 DUMAI & $\begin{array}{l}8228893828 \\
0\end{array}$ & Heristian1994@gmail.com \\
\hline 17 & ZULFAN HENDRI, M. PD & $\begin{array}{l}\text { MAN } 4 \text { KOTA } \\
\text { PEKANBARU }\end{array}$ & $\begin{array}{l}8527237043 \\
2\end{array}$ & zendrisulaini@gmail.com \\
\hline 18 & $\begin{array}{l}\text { SURYO PRANOTO, S.PD, } \\
\text { M.PD }\end{array}$ & MAN 4 PEKANBARU & $\begin{array}{l}8521354580 \\
6\end{array}$ & suryopranoto12@gmail.com \\
\hline 19 & $\begin{array}{l}\text { ICHSAN KUMAR } \\
\text { KAMPARI, S.PD }\end{array}$ & MAN 4 PEKANBARU & $\begin{array}{l}8536644200 \\
1\end{array}$ & Ichsankampari@gmail.com \\
\hline 29 & $\begin{array}{l}\text { ROLIASTA TARIGAN, } \\
\text { M.PD }\end{array}$ & MAN 4 PEKANBARU & $\begin{array}{l}8211494185 \\
9\end{array}$ & roliasta.tarigan@gmail.com \\
\hline 21 & SUKINAH, S.PD & SMPN 9 DUMAI & $\begin{array}{l}8238845459 \\
1\end{array}$ & sukinah937@gmail.com \\
\hline
\end{tabular}

Melakukan persiapan pelaksanaan dengan membuat flayer dan melakukan pendataan peserta yang merupakan guru MAN4 Kota Pekanbaru sebanyak 21 orang, seperti terlihat pada Gambar 2 dan Tabel 1. 


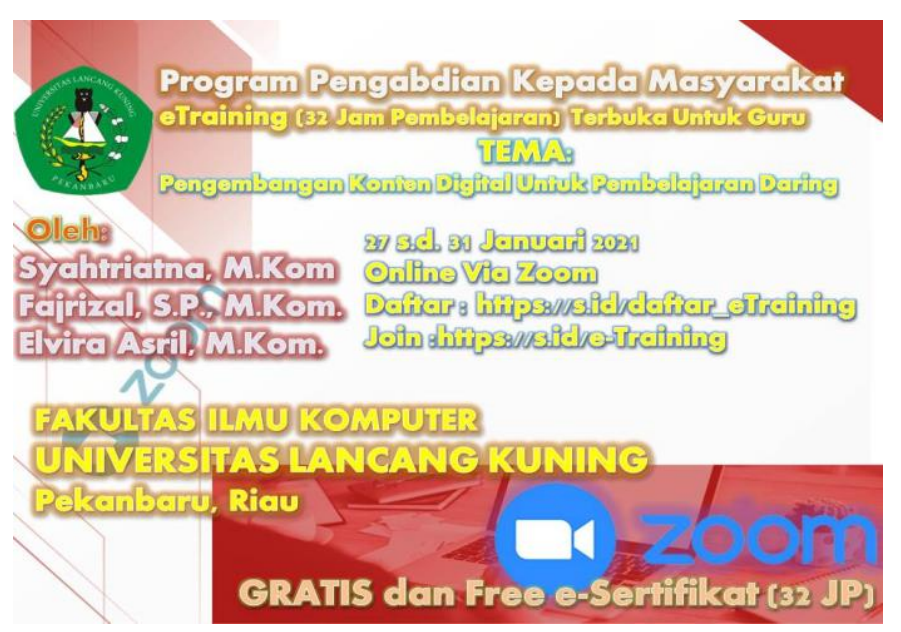

Gambar 2. Flayer

Selanjutnya dilakukan pengukuran kemampuan awal peserta dengan pertayaan dan jawaban seperti terlihat pada Tabel 2.

Tabel 2. Kuisioner Awal

\begin{tabular}{|c|c|c|}
\hline NO & Pertanyaan & Jawaban \\
\hline 1 & $\begin{array}{l}\text { Berapa sering Bapak/ Ibu menggunakan aplikasi dibawah ini } \\
\text { [Camtasia] }\end{array}$ & $\begin{array}{l}\text { Tidak Pernah (15), Kadang-kadang } \\
\text { (5)Sering (1) }\end{array}$ \\
\hline 2 & $\begin{array}{l}\text { Berapa sering Bapak/ Ibu menggunakan aplikasi dibawah ini } \\
\text { [Youtube] }\end{array}$ & $\begin{array}{l}\text { Kadang-kadang(10), Sangat Sering } \\
\text { (11) }\end{array}$ \\
\hline 3 & $\begin{array}{l}\text { Berapa sering Bapak/ Ibu menggunakan aplikasi dibawah ini [Power } \\
\text { Point] }\end{array}$ & $\begin{array}{l}\text { Kadang-kadang(9), Sangat Sering } \\
\text { (12) }\end{array}$ \\
\hline 4 & Menggunakan apakah Bapak/ Ibu mengakses aplikasi di atas & Laptop(20), HP(1) \\
\hline 5 & Untuk Apakah Bapak/ Ibu menggunakan Aplikasi Youtube & $\begin{array}{l}\text { Proses Belajar (17), Hiburan (2), } \\
\text { Menambah Pengetahuan(2) }\end{array}$ \\
\hline 6 & $\begin{array}{l}\text { Terkait pembuatan materi belajar untuk pembelajaran daring } \\
\text { dengan menggunakan aplikasi Camtasia, bagaimanakah penilaian } \\
\text { Bapak/ Ibu terkait dengan cara penggunaan/ pembuatannya }\end{array}$ & Tidak Pernah (18), Sulit (3) \\
\hline 7 & $\begin{array}{l}\text { Terkait pembuatan materi belajar untuk pembelajaran daring } \\
\text { dengan menggunakan situs Youtube, bagaimanakah penilaian } \\
\text { Bapak/ Ibu terkait dengan cara penggunaan/ pembuatannya }\end{array}$ & $\begin{array}{l}\text { Tidak Pernah (2), Sulit (13), } \\
\text { Mudah(6) }\end{array}$ \\
\hline 8 & $\begin{array}{l}\text { Terkait pembuatan materi belajar untuk pembelajaran daring } \\
\text { dengan menggunakan aplikasi Powerpoint, bagaimanakah penilaian } \\
\text { Bapak/ Ibu terkait dengan cara penggunaan/ pembuatannya }\end{array}$ & Sulit (3), Mudah(18) \\
\hline 9 & $\begin{array}{l}\text { Adakah Bapak/ Ibu pernah mendengar tentang keluhan siswa } \\
\text { terkait kurang menariknya konten dari materi pembelajaran daring } \\
\text { yang selama ini dilaksanakan }\end{array}$ & Ya(18), Tidak(3) \\
\hline 10 & $\begin{array}{l}\text { Apakah Bapak/ Ibu memerlukan pengetahuan/ keterampilan untuk } \\
\text { membuat konten pembelajaran yang menarik dan interaktif }\end{array}$ & $\mathrm{Ya}(21)$ \\
\hline
\end{tabular}

Berdasarkan hasil dari jawaban peserta terhadap pengukuran awal yang dilakukan, terlihat bahwa dari 3 aplikasi yang ditanyakan, hanya MS.Powerpoint yang dapat digunakan dan digunakan oleh sebagian peserta. Sementara untuk aplikasi Youtube dan Camtasia, tidak pernah digunakan dan dianggap sulit oleh sebagian peserta.

Setelah melakukan pendataan awal terhadap kemampuan dan pemahaman peserta terkaiit dengan materi yang akan disampaikan, selanjutnya dilakukan pelaksanaan pemaparan secara daring dalam rangka persiapan pelaksanaan kegiatan secara luring, seperti terlihat pada Gambar 3. 


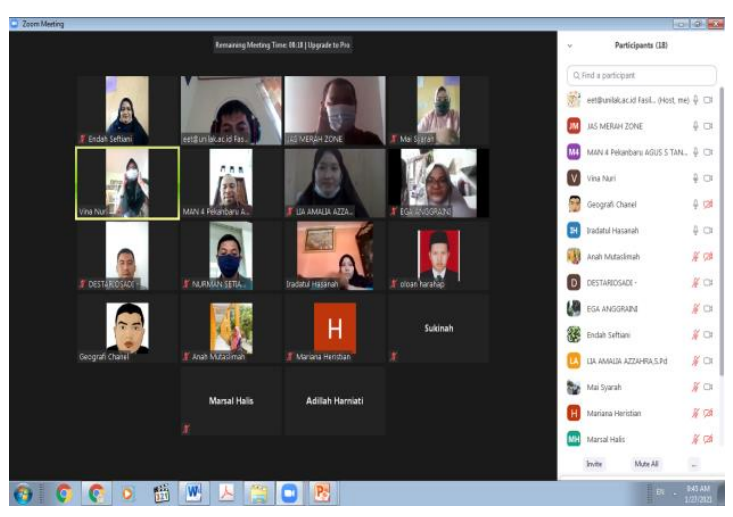

(a)

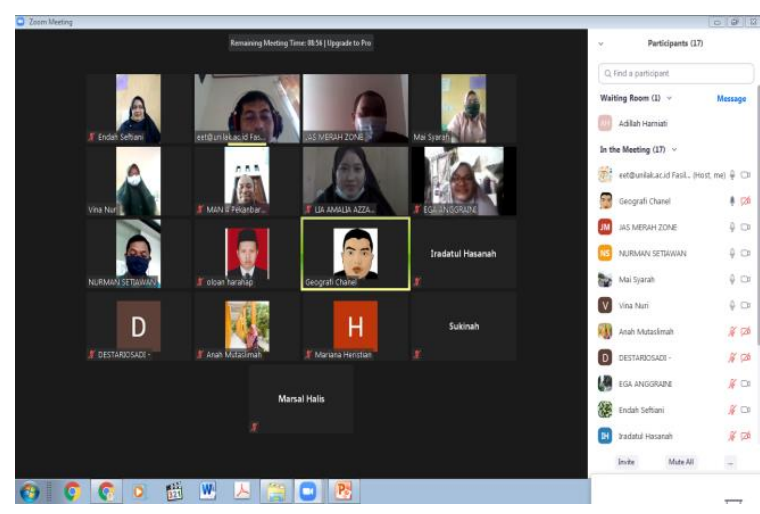

(b)

Gambar 3. (a)(b) Sosialisasi Kepada Peserta

Setelah menyampaikan sosialisasi secara daring kepada peserta terkait persiapan dan kebutuhan perangkat dan aplikasi untuk kegiatan ceramah dan workshop, selanjutnya di laksanakan kegiatan ceramah dan workshop yang bertempat di salah satu ruang kelas MAN 4 Kota Pekanbaru. Kegaiatan ini dilaksanaan dalam bentuk Ceramah oleh Pemateri tentang penggunaan aplikasi MS.Powerpoint, Youtube dan Camtasia untuk meningkatkan efektivitas pembelajaran daring dalam kondisi Covid-19. Kemudian dilanjutkan dengan kegiatan praktek penggunaan aplikasi dan pembuatan media pembelajaran oleh peserta. Kegiatann ini dilaksanakan selama 3 hari. Sebagai pemateri dari kegiatan ini adalah Tim Pelaksana kegiatan pengabdian, yaitu Fajrizal, S.P., M.Kom dan Syahtriatna D., M.Kom, yang di ikuti oleh guru MAN 4 Kota Pekanbaru sebagai peserta sebagaimana terlihat pada gambar 4.

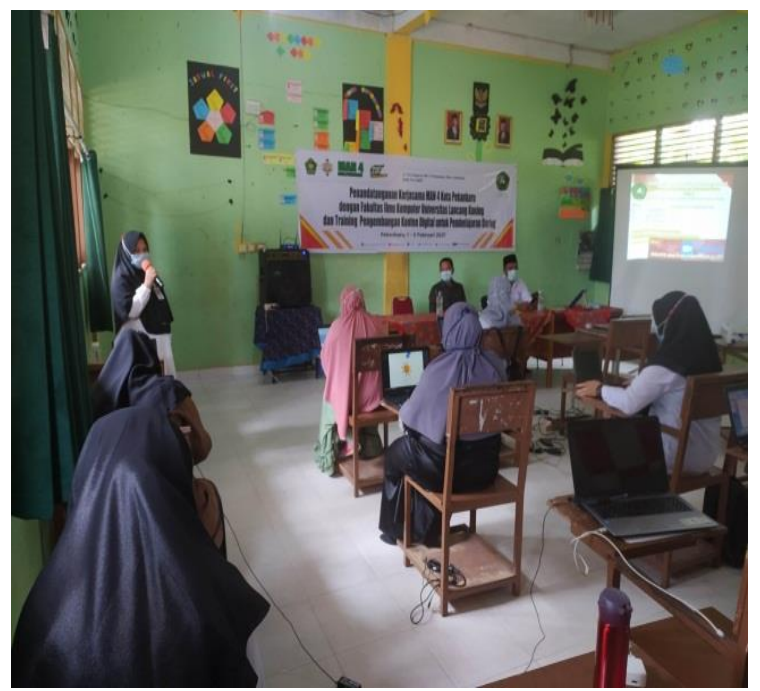

(a)

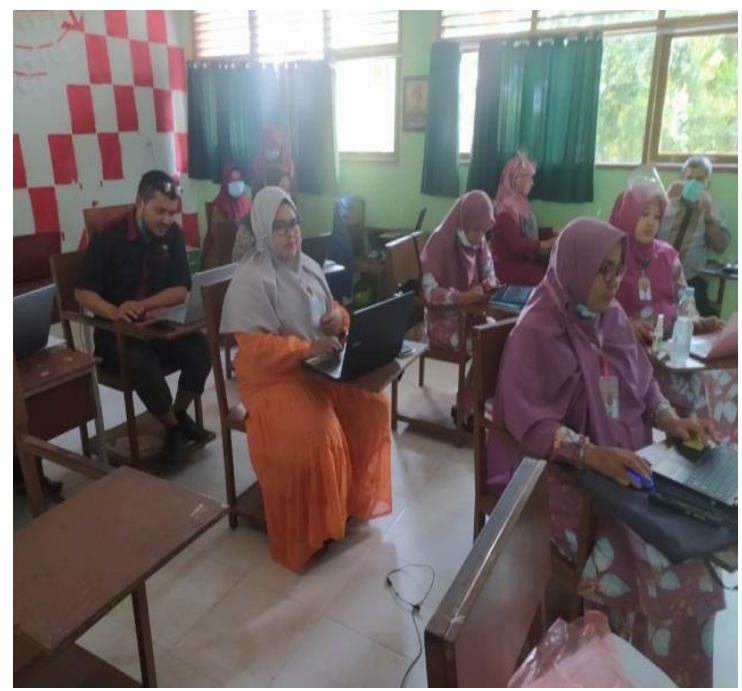

(b)

Gambar 4. (a)(b) Pelaksanaan Kegiatan

Setelah dilaksanakan kegiatan ceramah dan workshop, selanjutnya dilakukan kembali pengukuran terhadap tingkat pemahaman peserta. 
Tabel 3. Pengukuran Hasil Kegiatan

\begin{tabular}{|l|l|l|}
\hline NO & Pertanyaan & Jawaban \\
\hline 1 & $\begin{array}{l}\text { Terkait pembuatan materi belajar untuk pembelajaran daring } \\
\text { dengan menggunakan aplikasi Camtasia, bagaimanakah } \\
\text { penilaian Bapak/ Ibu terkait dengan cara penggunaan/ } \\
\text { pembuatannya }\end{array}$ & Mudah(21) \\
\hline 2 & $\begin{array}{l}\text { Terkait pembuatan materi belajar untuk pembelajaran daring } \\
\text { dengan menggunakan situs Youtube, bagaimanakah } \\
\text { penilaian Bapak/ Ibu terkait dengan cara penggunaan/ } \\
\text { pembuatannya }\end{array}$ & Mudah(21) \\
\hline 3 & $\begin{array}{l}\text { Terkait pembuatan materi belajar untuk pembelajaran daring } \\
\text { dengan menggunakan aplikasi Powerpoint, bagaimanakah } \\
\text { penilaian Bapak/ Ibu terkait dengan cara penggunaan/ } \\
\text { pembuatannya }\end{array}$ & Mudah(21) \\
\hline
\end{tabular}

Hasil pengukuran yang dilakukan kepada peserta, menggunakan 3 pertanyaan yang sama dengan pertanyaan awal, memperlihatkan adanya perbedaan jawaban. Saat sebelum pelaksanaan kegiatan ceramah dan workshop, untuk pembuatan media pembelajaran menggunakan aplikasi camtasia tidak ada peserta yang memberikan jawaban mudah, untuk penggunaan aplikasi youtube ada sebanyak 6 orang peserta yang memberikan jawaban mudah dan untuk penggunaan aplikasi MS powerpoint ada sebanyak 18 peserta yang memberikan jawaban mudah. Setelah dilaksanakan kegiatan ceramah dan workshop selama 3 hari, maka terhadap 3 pertanyaan penggunaan aplikasi camtasia, youtube dan powerpoint, sebanyak 21 atau keseluruhan peserta mengatakan mudah.

Hasil pengukuran ini juga didukung oleh hasil media yang dibuat oleh peserta, dimana pada akhir kegiatan workshop, peserta mampu membuat konten digital dengan menggunakan 3 aplikasi yang telah di jelaskan.

\section{Kesimpulan}

Dengan adanya kegiatan pengabdian dalam bentuk pelatihan daring terkait tentang pengembangan konten digital, maka dapat disimpulkan

1. Terjadinya peningatan pemahaman dan keterampilan peserta dalam membuat konten digital dengan menggunakan Aplikasi Camtasia, Youtube dan Powerpoint, dimana pada saat belum dilaksanakan kegiatan pengabdian dalam bentuk ceramah dan workshop, tidak ada peserta mengatakan mudah dalam membuat konten digital dengan menggunakan Camtasia, hanya 6 peserta yang mengatakan mudah membuat konten media menggunakan Youtube serta 18 peserta yang mengatakan mudah membuat konten digital dengan menggunakan power point, setelah dilaksanakan kegiatan pengabdian, seluruh peserta mengatakan mudah dalam membuat konten digital dengan menggunakan ketiga aplikasi tersebut .

2. Peningkatan kemampuan dan keterampilan guru MAN 4 Kota Pekanbaru dalam membuat konten digital, akan menjadi sebuah solusi dalam meningkatkan efektifitas pembelajaran, karena guru-guru dapat mengembangkan dan membuat variasi materi pembelajaran yang lebih mudah dipahami dan lebih menarik untuk diikuti oleh peserta didik.

\section{Ucapan Terima Kasih}

Penulis mengucapkan terima kasih kepada dekan Fakultas Ilmu Komputer beserta jajaran yang telah memberi dukungan pembiayaan dan sarana terhadap pengabdian ini, sehingga kegiatan ini dapat dilaksanakan dengan baik. 


\section{DAFTAR PUSTAKA}

Costaner, L., Febriadi, B., \& others. (2020). Pelatihan Dasar Membuat Aplikasi Android App Inventor Pada Sekolah Menengah Atas Saint Siak Sri Indrapura. Dinamisia: Jurnal Pengabdian Kepada Masyarakat, 4(3), 525-530.

Derry, J. (n.d.). BOOK-Jan Derry-Vygotsky philosophy and education-Wiley Blackwell (2013).

Dhawan, S. (2020). Online learning: A panacea in the time of COVID-19 crisis. Journal of Educational Technology Systems, 49(1), 5-22.

Dhika, H., Destiawati, F., Surajiyo, S., \& Jaya, M. (2021). Distance Learning During the Pandemic Period of COVID-19 with Zoom and Webex Comparison.

Diknas. UNDANG-UNDANG REPUBLIK INDONESIANOMOR 20 TAHUN 2003TENTANGSISTEM PENDIDIKAN NASIONAL (2003). https://doi.org/10.16309/j.cnki.issn.1007-1776.2003.03.004

George, M. L. (2020). Effective Teaching and Examination Strategies for Undergraduate Learning During COVID-19 School Restrictions. Journal of Educational Technology Systems, 49(1), 2348.

Ghislandi, P. (2012). elearning - Theories, Design, Software and Applications. eLearning Theories, Design, Software and Applications. https://doi.org/10.5772/2533

Hall, R., \& Greeno, J. G. (2012). Conceptual Learning. 21st Century Education: A Reference Handbook 21st century education: $A$ reference handbook. https://doi.org/10.4135/9781412964012.n23

Holford, J. (2003). The Theory and Practice of Learning. The Theory and Practice of Learning. https://doi.org/10.4324/9780203465653

Joyce, B., \& Weil, M. (2003). Models of Teaching Fifth Edition, 478. Retrieved from http://tb3809ld86. download2.org/dl2.php?id=34346314\&h=baabf1189c6a4e31ffcc842feee0f5 e7\&u=cache\&ext=pdf\&n=Models of teaching

Rodrigues, S. (2018). Ng Wan: New Digital Technology in Education: Conceptualizing Professional Learning for Educators. Technology, Knowledge and Learning (Vol. 23). https://doi.org/10.1007/s10758-015-9267-3

Siddiq, F., Gochyyev, P., \& Wilson, M. (2017). Learning in Digital Networks - ICT literacy: A novel assessment of students' 21st century skills. Computers and Education, 109, 11-37. https://doi.org/10.1016/j.compedu.2017.01.014

Taslim, T., Toresa, D., \& Djusar, S. (2017). Pengaruh Pengaplikasian E-learning Terhadap Hasil Belajar (Studi Kasus: Mahasiswa Keamanan Komputer Fasilkom Unilak). INOVTEK-Seri Informatika, 2(2), 182-188.

Trivantis. (2016). Making eLearning Accessible. 